
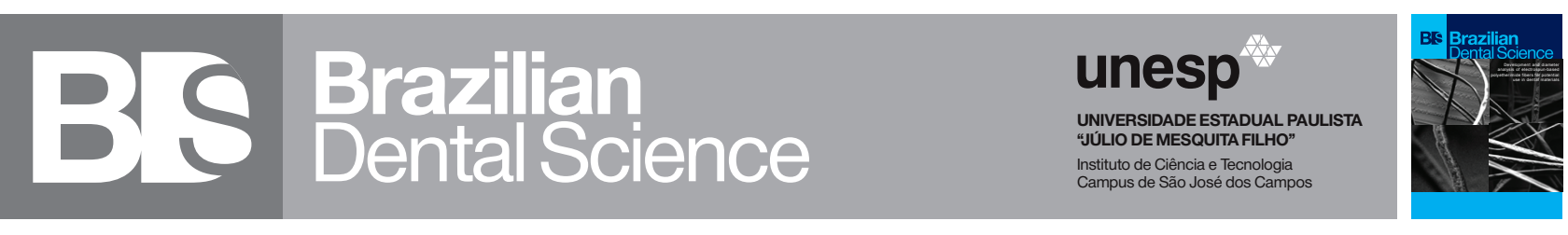

\title{
Emotional, behavioral, and social effects of anterior tooth loss: a cross-sectional study
}

\author{
Efeitos emocionais, comportamentais e sociais da perda dentária anterior: um estudo tranversal \\ Mohammed SAYED ${ }^{1}$, Honey LUNKAD ${ }^{1}$, Carlos Alberto JURADO ${ }^{2}$, Akimasa TSUJIMOTO ${ }^{3}$, Walaa Magdy AHMED ${ }^{4}$ \\ 1 - Department of Prosthetic Dental Sciences, Jazan University College of Dentistry, Jazan, KSA. \\ 2 - Division of Digital Dentistry, A.T. Still University Arizona School of Dentistry \& Oral Health, Mesa, Arizona, USA. \\ 3 - Department of Operative Dentistry, Nihon University School of Dentistry, Tokyo, Japan. \\ 4 - Department of Restorative and Aesthetic Dentistry, Faculty of Dentistry, King Abdulaziz University, Jeddah, KSA.
}

\section{ABSTRACT}

Objective: The study aims to evaluate the emotional, behavioural, and social effects of single or multiple anterior tooth loss. It also compares the effectiveness of the removable and fixed prosthesis to address the impact of anterior tooth loss. Material and Methods: The study was carried out on 70 subjects who presented to the Department of Prosthetic Dental Sciences. A questionnaire was distributed and the data were statistically analyzed using SPSS version 18.0 and values less than $0.05 \%$ were considered statistically significant. Results: The participant's difficulty to accept loss of their anterior tooth, embarrassment and confidence were changed significantly after wearing the prosthesis $(\mathrm{P}<$ 0.05). Moreover, fixed partial denture had more effect than removal partial denture. It was claimed by $62.9 \%$ of the participants that they were not prepared for the effect of tooth loss and 47.1\% of them thought that a prior explanation from the dentist would have helped them overcome their fear of losing their teeth. Conclusion: The maximum impact of anterior tooth loss was felt on confidence followed by embarrassment. The participants felt more comfortable after wearing their prosthesis. Fixed partial denture had more effect than removable partial denture.

\section{KEYWORDS}

Emotional; Behavioral; Social; Anterior tooth loss.

\section{RESUMO}

Objetivo: O estudo visa avaliar os efeitos emocionais, comportamentais e sociais da perda dentária anterior unitária ou múltipla. Ele também compara a eficácia da protese removível e da fixa para lidar com o impacto da perda dentária anterior. Material e Métodos: $O$ estudo foi realizado em 70 indivíduos que se apresentaram ao Department of Prosthetic Dental Sciences. Foi distribuído um questionário e os dados analisados estatisticamente no SPSS versão 18.0 e valores inferiores a 0,05\% foram considerados estatisticamente significativos. Resultados: A dificuldade do participante em aceitar a perda de seu dente anterior, constrangimento e confiança mudaram significativamente após usar a prótese $(\mathrm{P}<0,05)$. Além disso, a prótese parcial fixa teve mais efeito do que a prótese parcial removível. Foi alegado por $62,9 \%$ dos participantes que não estavam preparados para o efeito da perda dentária e 47,1\% deles achavam que uma explicação prévia do cirurgião-dentista os teria ajudado a superar o medo de perder os dentes. Conclusão: O impacto máximo da perda dentária anterior foi sentido na confiança, seguido de constrangimento. Os participantes se sentiram mais confortáveis após o uso de suas próteses. A prótese parcial fixa teve mais efeito do que a prótese parcial removível.

\section{PALAVRAS-CHAVE}

Emocional; Comportamental; Social; Perda do dente anterior. 


\section{INTRODUCTION}

$I^{\mathrm{n}}$ ndividuals with dentofacial abnormalities Iexperience social and psychological consequences as teeth deformation has an adverse effect on their facial expression, speech, and eating ability [1-3]. Edentulism negatively influences the oral function, social life, and day to day activities of an individual [4]. Loss of anterior teeth may force the individual to avoid participation in social activities because they are embarrassed to speak, smile or eat in public, leading to isolation [5]. Several researches in dentistry have been done on physical aspects of tooth loss [6-9]. Recently, attention has been given to the emotional effects of tooth loss.

Studies have advocated that the outcome of these abnormalities vary based on the individual's cultural differences and lifestyles [10,11]. For instance, individuals from London take longer to come to terms with their tooth loss. Studies also indicated that Hong Kong group was most prepared for effects of tooth loss [10]; however, it restricted their daily activities. The awareness and availability of dental treatment and education was also a matter of concern in this issue. This cross-sectional survey was conducted to study a representative sample of the Saudi Arabian population with regards to the emotional, behavioral, and social impact of single or multiple anterior tooth loss over a predetermined period of time. It also compares the effectiveness of prosthesis to address the effects of anterior tooth loss. This study is one of its kind because none of the studies compare all the aspects together (emotional, behavioral and social) relevant to anterior tooth loss, along with the effect of treatment on the behavioral, emotional and social aspects and the comparison of various modes to prepare the patients to overcome this emotional turmoil. Null hypotheses stated that there is no effect of single or multiple anterior tooth loss on the emotional, behavioral and social behavior of individuals.

\section{MATERIALS AND METHODS}

\section{Study design}

This descriptive cross-sectional study was conducted in the Department of Prosthetic Dental Sciences. A total number of 70 patients undergoing prosthodontics treatment for replacement of missing anterior teeth either by removable partial denture (RPD) or tooth supported fixed partial denture (FPD) were selected for the study over a period of six months. First, the sample size was set based on the similar previous studies, especially those studies performed by Fiske and Davis group. A sample size of 150 individuals was set in the original study protocol, which was sent to the IRB at Jazan University College of Dentistry for approval. Following approval, a pilot study was performed at the early stage of data collection to identify the actual sample size that will meet the targeted power level. The sample size based on $80 \%$ power analysis was 85 . The data collection was done over a year period following robust inclusion and exclusion criteria and based on the approved protocol; therefore, only 70 individuals met those criteria and were included in the study. Ethical approval was acquired from the IRB Committee; while, written consent forms were completed by the patients prior to intervention. The patients were communicated about data anonymity and confidentiality. The study design was retrospective in nature since the patients participated in the study after their complete treatment. The data was collected through a survey using a close-ended questionnaire.

\section{Inclusion and Exclusion Criteria}

All individuals in the age group of 2060 years, who had lost their teeth within a period of 12 months before the prosthodontic rehabilitation, were selected. Patients, who had received removable or fixed prostheses, were included in the study. The patients who had received dental implants for restoration of missing teeth were excluded from the study due to insufficient number of patients treated with 
Implants during that period. The participants who were physically or mentally unstable due to any reasons were also not included in the study to prevent any biasness. The questionnaire was then distributed randomly among the patients, who had undergone replacement of missing anterior teeth (maxillary or mandibular), either by removable partial dentures (RPD) or tooth supported fixed partial dentures (FPD).

\section{Questionnaire}

The questionnaire was developed using the findings of previous studies for investigating the emotional, behavioral, and social effects of tooth loss $[10,12]$. The questionnaire was translated into Arabic language for the participants who had difficulty in answering questions in English. The original English written questionnaire was based on previous literature with addition of new questions relevant to our study parameters (questionnaire attached). This questionnaire was checked for clarity and ease of understanding among prosthodontics faculty. The questionnaire was then translated by a professional translation office to Arabic Language to be easily read and understood by patients since it is the native language in the country. The translated questionnaire was checked for clarity by native Arabic speakers and a pilot study was conducted to validate the questionnaire and perform power analysis. The questionnaire comprised of questions regarding the acceptance of tooth loss, its impact on self-confidence and various aspects of daily living activities. It also covered aspects of emotional disturbance, confidence level, and social performance after tooth replacement.

\section{Statistical Analysis}

The data from the study was then analyzed using Statistical Package for Social Sciences (SPSS version 18.0). Mean, standard deviation, and frequency distribution charts were made wherever appropriate. Chi square test was then used for data analysis. P-values were calculated and values less than $0.05 \%$ were considered statistically significant.

\section{RESULTS}

The study population included 30 (43\%) males and 40 (57\%) females. The mean age of the subjects in this study was $37.87 \pm 11.32$ years ranged between 20-60 years. During the period of the study, 60 (86\%) of subjects presented with partial dentures. Out of them, $44(73 \%)$ were treated with fixed partial denture and 16 (27\%) were treated with removable partial denture. Therefore, responses of 60 subjects were available for data analysis.

For the total sample, 31 (68.9\%) participants of those who experienced difficulty in accepting teeth missing $(n=45)$ had no difficulty in accepting the prosthesis (Table I). Only 1 participant out of those who had not difficulty in accepting missing teeth had a difficulty in accepting the prosthesis (RPD). The difference was highly significant for the total sample $(\mathrm{P}<$ 0.001). However, it was significant for among FPD wearers $(\mathrm{P}<0.001)$ and non-significant among RPD wearers $(\mathrm{P}=0.219)$.

Although more than $70 \%$ of the total sample found their appearance different after wearing the prosthesis (Table II), this difference was not significant. The appearance was also not significant among each group ( $P>0.05)$. Most participants who were embarrassed with missing teeth, did not have this feeling after wearing the prosthesis, with significant difference $(\mathrm{P}=0.005)$. Among groups, the difference was significant for FPD wearers $(P=0.036)$ and non-significant for RPD wearers $(\mathrm{P}=0.228)$ (Table III).

Confidence with prosthesis was significantly more than without prosthesis for the total sample and for the FPD wearers group $(\mathrm{P}<0.001)$. However, 3 out of 8 participants, who felt no effect with missing teeth, felt less confident after wearing the removable partial denture (Table IV). As shown in Table V, feeling with prosthesis was not that big different than feeling without 
prosthesis for the total sample $(\mathrm{P}=0.171)$ and for the RPD wearers group $(\mathrm{P}=0.172)$. However, the difference was significant among the FPD wearers $(P=0.046)$. Regarding the feeling of people around (Table VI), there was no significant difference between perception of the feeling before and after wearing the prosthesis among the total sample as well as among each group $(\mathrm{P}>0.05)$.

More than $60 \%$ of the participants claimed that they were not prepared for the effect of tooth loss, and $47.1 \%$ thought that a prior explanation from the dentist would have helped them overcome their fear of losing their teeth.

Table I-Responses of subjects regarding difficulty in accepting the teeth missing and prosthesis

\begin{tabular}{|c|c|c|c|c|c|c|}
\hline & & & \multicolumn{3}{|c|}{$\begin{array}{c}\text { Difficulty of acceptance of } \\
\text { prosthesis }\end{array}$} & \multirow[b]{2}{*}{$\mathbf{P}$} \\
\hline & & & No & Yes & Total & \\
\hline \multirow{9}{*}{$\begin{array}{l}\text { Difficulty of } \\
\text { acceptance of } \\
\text { missing teeth }\end{array}$} & \multirow{3}{*}{ Total } & No & $14(93.3)$ & $1(6.7)$ & 15 & \multirow{3}{*}{0.000} \\
\hline & & Yes & $31(68.9)$ & $14(31.1)$ & 45 & \\
\hline & & Total & $45(75.0)$ & $15(25.0)$ & 60 & \\
\hline & \multirow{3}{*}{ FPD } & No & $10(100.0)$ & $0(0.0)$ & 10 & \multirow{3}{*}{0.000} \\
\hline & & Yes & $26(76.5)$ & $8(23.5)$ & 34 & \\
\hline & & Total & $36(81.8)$ & $8(18.2)$ & 44 & \\
\hline & \multirow{3}{*}{ RPD } & No & $4(80.0)$ & $1(20.0)$ & 5 & \multirow{3}{*}{0.219} \\
\hline & & Yes & $5(45.5)$ & $6(54.5)$ & 11 & \\
\hline & & Total & $9(56.3)$ & $7(43.8)$ & 16 & \\
\hline
\end{tabular}

Table II - Responses of subjects regarding change of appearance with and without prosthesis

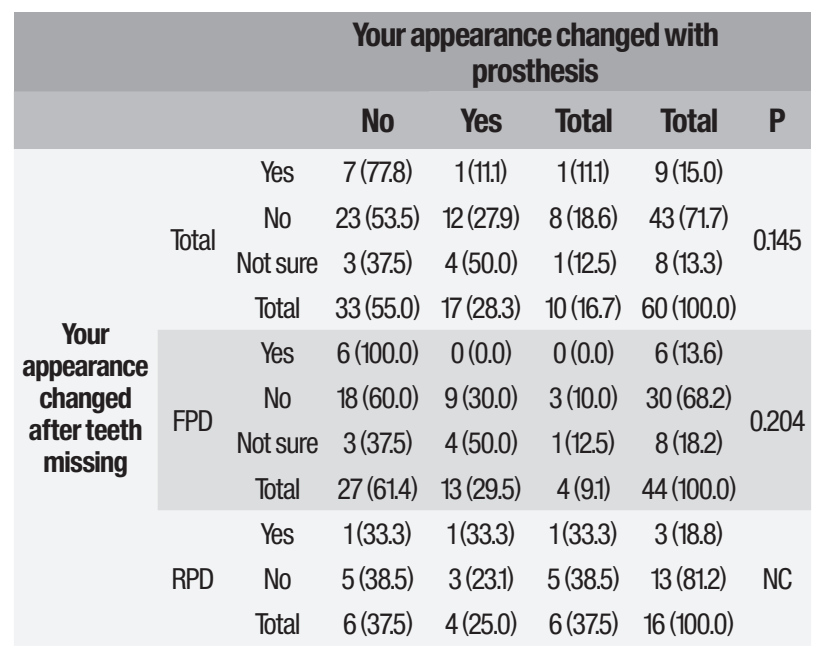

Table III - Responses of subjects regarding their feelings with and without prosthesis

\begin{tabular}{|c|c|c|c|c|c|c|c|}
\hline & & \multicolumn{6}{|c|}{ Embarrassed with prosthesis } \\
\hline & & & No & Yes & Total & Total & $\mathbf{P}$ \\
\hline \multirow{12}{*}{$\begin{array}{l}\text { Embarras- } \\
\text { sed with } \\
\text { missing } \\
\text { teeth }\end{array}$} & \multirow{4}{*}{ Total } & No & $23(82.1)$ & $4(14.3)$ & $1(3.6)$ & $28(46.7)$ & \multirow{4}{*}{0.005} \\
\hline & & Yes & $8(44.4)$ & $5(27.8)$ & $5(27.8)$ & $18(30.0)$ & \\
\hline & & Not sure & $9(64.3)$ & $0(0.0)$ & $5(35.7)$ & $14(23.3)$ & \\
\hline & & Total & $40(66.7)$ & $9(15.0)$ & $11(18.3)$ & $60(100.0)$ & \\
\hline & \multirow{4}{*}{ FPD } & No & $16(80.0)$ & $3(15.0)$ & $1(5.0)$ & $20(45.5))$ & \multirow{4}{*}{0.036} \\
\hline & & Yes & $6(42.9)$ & $4(28.6)$ & $4(28.6)$ & $14(31.8))$ & \\
\hline & & Not sure & $6(60.0)$ & $0(0.0)$ & $4(40.0)$ & $10(22.7)$ & \\
\hline & & Total & $28(63.6)$ & $7(15.9)$ & $9(20.5)$ & $44(100.0)$ & \\
\hline & \multirow{4}{*}{ RPD } & No & $7(87.5)$ & $1(12.5)$ & $0(0.0)$ & $8(50.0)$ & \multirow{4}{*}{0.228} \\
\hline & & Yes & $2(50.0)$ & $1(25.0)$ & $1(25.0)$ & $4(25.0)$ & \\
\hline & & Not sure & $3(75.0)$ & $0(0.0)$ & $1(25.0)$ & $4(25.0)$ & \\
\hline & & Total & $12(75.0)$ & $2(12.5)$ & $2(12.5)$ & $16(100.0)$ & \\
\hline
\end{tabular}

Table IV - Confidence of subjects with and without prosthesis

\begin{tabular}{|c|c|c|c|c|c|c|c|}
\hline & & & \multicolumn{5}{|c|}{ Confidence with prosthesis } \\
\hline & & & $\begin{array}{c}\text { No } \\
\text { effect }\end{array}$ & $\begin{array}{l}\text { More } \\
\text { confi- } \\
\text { dent }\end{array}$ & $\begin{array}{l}\text { Less } \\
\text { confi- } \\
\text { dent }\end{array}$ & Total & $\mathbf{P}$ \\
\hline \multirow{11}{*}{$\begin{array}{l}\text { Confidence } \\
\text { with mis- } \\
\text { sing teeth }\end{array}$} & \multirow{4}{*}{ Total } & No effect & $5(14.3)$ & $23(65.7)$ & $7(20.0)$ & $\begin{array}{c}35 \\
(58.3)\end{array}$ & \multirow{4}{*}{0.000} \\
\hline & & $\begin{array}{l}\text { More } \\
\text { confident }\end{array}$ & $1(100.0)$ & $0(0.0)$ & $0(0.0)$ & $1(1.7)$ & \\
\hline & & $\begin{array}{l}\text { Less } \\
\text { confident }\end{array}$ & $9(37.5)$ & $15(62.5)$ & $0(0.0)$ & $\begin{array}{c}24 \\
(40.0)\end{array}$ & \\
\hline & & Total & $15(25.0)$ & $38(63.3)$ & $7(11.7)$ & $\begin{array}{c}60 \\
(100.0)\end{array}$ & \\
\hline & \multirow{4}{*}{ FPD } & No effect & $4(14.8)$ & $19(70.4)$ & $4(14.8)$ & $\begin{array}{c}27 \\
(61.4)\end{array}$ & \multirow{4}{*}{0.000} \\
\hline & & $\begin{array}{c}\text { More } \\
\text { confident }\end{array}$ & $1(100.0)$ & $0(0.0)$ & $0(0.0)$ & $1(2.3)$ & \\
\hline & & $\begin{array}{l}\text { Less } \\
\text { confident }\end{array}$ & $6(37.5)$ & $10(62.5)$ & $0(0.0)$ & $\begin{array}{c}16 \\
(36.3)\end{array}$ & \\
\hline & & Total & $11(25.0)$ & $29(65.9)$ & $4(9.1)$ & $\begin{array}{c}44 \\
(100.0)\end{array}$ & \\
\hline & \multirow{3}{*}{ RPD } & No effect & $1(12.5)$ & $4(50.0)$ & $3(37.5)$ & $8(50.0)$ & \multirow{3}{*}{ NC } \\
\hline & & $\begin{array}{l}\text { Less } \\
\text { confident }\end{array}$ & $3(37.5)$ & $5(62.5)$ & $0(0.0)$ & $8(50.0)$ & \\
\hline & & Total & $4(25.0)$ & $9(56.3)$ & $3(18.8)$ & $\begin{array}{c}16 \\
(100.0)\end{array}$ & \\
\hline
\end{tabular}


Table V - Responses of subjects regarding their satisfaction with and without prosthesis

\begin{tabular}{|c|c|c|c|c|c|c|c|}
\hline & & & \multicolumn{5}{|c|}{ Satisfaction with prosthesis } \\
\hline & & & $\begin{array}{l}\text { Noth- } \\
\text { ing }\end{array}$ & $\begin{array}{l}\text { So } \\
\text { good }\end{array}$ & Good & Total & $\mathbf{P}$ \\
\hline \multirow{12}{*}{$\begin{array}{l}\text { Satisfaction } \\
\text { with mis- } \\
\text { sing teeth }\end{array}$} & \multirow{4}{*}{ Total } & Nothing & $0(0.0)$ & $2(40.0)$ & $3(60.0)$ & $5(8.3)$ & \multirow{4}{*}{0.171} \\
\hline & & So bad & $4(21.1)$ & $7(36.8)$ & $8(42.1)$ & $19(31.7)$ & \\
\hline & & Bad & $5(13.9)$ & $18(50.0)$ & $13(36.1)$ & $\begin{array}{c}36 \\
(60.0)\end{array}$ & \\
\hline & & Total & $9(15.0)$ & $27(45.0)$ & $24(40.0)$ & $\begin{array}{c}60 \\
(100.0)\end{array}$ & \\
\hline & \multirow{4}{*}{ FPD } & Nothing & $0(0.0)$ & $2(66.7)$ & $1(33.3)$ & $3(6.8)$ & \multirow{4}{*}{0.046} \\
\hline & & So bad & $1(8.3)$ & $6(50.0)$ & $5(41.7)$ & $\begin{array}{c}12 \\
(27.3)\end{array}$ & \\
\hline & & Bad & $5(17.2)$ & $15(51.7)$ & $9(31.0)$ & $\begin{array}{c}29 \\
(65.9)\end{array}$ & \\
\hline & & Total & $6(13.6)$ & $23(52.3)$ & $15(34.1)$ & $\begin{array}{c}44 \\
(100.0)\end{array}$ & \\
\hline & \multirow{4}{*}{ RPD } & Nothing & $0(0.0)$ & $0(0.0)$ & $2(100.0)$ & $2(12.6)$ & \multirow{4}{*}{0.172} \\
\hline & & So bad & $3(42.9)$ & $1(14.3)$ & $3(42.9)$ & $7(43.7)$ & \\
\hline & & Bad & $0(0.0)$ & $3(42.9)$ & $4(57.1)$ & $7(43.7)$ & \\
\hline & & Total & $3(18.8)$ & $4(25.0)$ & $9(56.3)$ & $\begin{array}{c}16 \\
(100.0)\end{array}$ & \\
\hline
\end{tabular}

Table VI - Responses of subjects regarding feelings of people around them with and without prosthesis

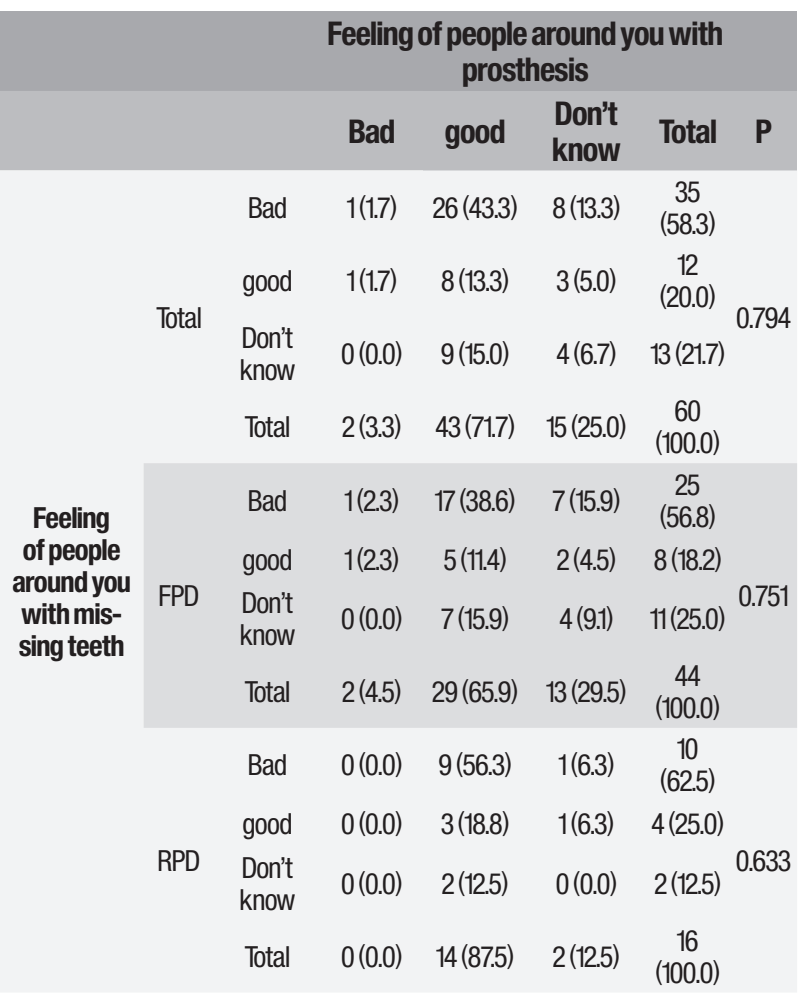

\section{DISCUSSION}

The study aimed to evaluate the emotional, behavioral and social effect of single and multiple anterior tooth loss in Saudi population. It also compared the effectiveness of removable partial denture or fixed partial dentures to address the effects of anterior tooth loss. The use of questionnaire in the study is an accepted and commonly used method of data collection. The main advantage of this method is that it helps to reach a large (often specified) number of subjects at a relatively low cost and effort. The results of the current study were found to be consistent with the study conducted by Nordenram et al. [13]. It showed that loss of teeth has a significant negative impact on the oral health, as well as the confidence level of an individual. However, oral rehabilitation can significantly restore the self-worth and quality of life.

Another study conducted by Fiske et al. [10] concluded results similar to the findings of the current study. Fifty edentulous patients were recruited that were undergoing prosthetic dental care. The study identified, bereavement, alteration in socializing, lack of self-confidence, and premature ageing as a reaction to tooth loss. Moreover, the results suggested that tooth loss has significant impact on the personal life of an individual even for those who struggles with prosthetic dentures. Another study conducted by Batista et al. [14] evaluated the influence of tooth loss related to number and position on oral health of adults reported similar results. A cross-sectional study design was chosen for the study since it helps in evaluating a number of factors at one time. [15, 16] The factors evaluated, included; dental services, health literacy, socioeconomic, demographics, and clinical variables of the patients. The results suggested that edentulism had a negative impact on the quality of life of patients, which are in agreement with some previous studies. [17-20] 
It was also found that the patients expressed wide range of emotions on losing the teeth from anger to being sad or depressed. However, some patients expressed a sense of relief probably due to the amount of pain they had to bear before the loss of the tooth. The present study evaluated different mode of patient preparation to overcome the effect of tooth loss. The various options given to the patient were a video for preparing them about the effects of tooth loss or a leaflet or talking to someone who had already experienced tooth loss and /or an explanation from the dentist. Large number of participants believed that an explanation from the dentist would be more helpful, demonstrating the major role dentist could play to better prepare the patient with the consequences of tooth loss. Our study also concluded that $77.1 \%$ of subjects had difficulties in accepting tooth loss and majority of the participants felt more confident and comfortable after wearing the prosthesis. The subjects even felt more comfortable with the prosthesis in terms of eating and were overall more satisfied with the appearance after wearing the prosthesis.

The present study has not examined the prevalence and incidence as it is considered a pilot cross-sectional study design. Sample subjects need to be in large numbers and widely scattered to be truly representative of the study population. Hence further studies with large sample size are required. The authors aimed to compare emotional, psychological and social changes in behavior after replacing teeth with dental implant supported restoration and compare it with conventional removable or fixed partial denture. Also, the results were overestimated in the present study as the study was carried out in people seeking dental care. Therefore, future studies outside the healthcare environment should be carried out. It also directs the future researches to evaluate the role of dentist to intervene and educate the patient before extraction of the tooth and educate them about the objective appraisal of treatment options.

\section{CONCLUSION}

The study concluded that partially edentulous people found it difficult to accept the loss of their anterior tooth. The acceptance of tooth loss and duration was also found to be challenging aspects for the participants. Also, the loss of tooth had a significant impact on the confidence level of the participants. Furthermore, speech and appearance were significantly influenced by the anterior tooth loss. Prior explanation from the dentist about the effective restoration of the lost tooth could help the patient better cope up with their emotional, social and behavioral outlook.

\section{Acknowledgments}

The authors are grateful to College of Dentisty, Jazan University and the participants for their support during the development of the manuscript.

\section{Funding}

This is a self-funded study

\section{Conflict of interest}

The authors have no proprietary, financial, or other personal interest of any nature or kind in any product, service, and/or company that is presented in this article.

\section{Regulatory Statement}

This study was conducted in accordance with all the provisions of the local human subjects oversight committee guidelines and policies of Jazan University, KSA.

\section{REFERENCES}

1. Newton JT, Fiske J, Foote 0, Frances C, Loh IM, Radford DR Preliminary study of the impact of loss of part of the face and its prosthetic restoration. $J$ Prosthet Dent. 1999;82:585-90. doi: 101016/s0022-3913(99)70058-2. 
2. McGrouther DA. Facial disfigurement: the last bastion of discrimination. British Medical Journal Publishing Group, 1997.

3. Allen PF, McMillan AS. The impact of tooth loss in a denture wearing population: an assessment using the Oral Health Impact Profile. Community DentHealth. 1999 Sep;16(3):176-80.PMID: 10641078

4. Heydecke G, Thomason JM, Lund JP, Feine JS The impact of conventional and implant supported prostheses on social and sexual activities in edentulous adults Results from a randomized trial 2 months after treatment. JDent. 2005;33:649-57. doi:10.1016/j.jdent.2005.01.003.

5. Rodrigues SM, Oliveira AC, Vargas AM, Moreira AN, EFEF Implications of edentulism on quality of life among elderly. Int J Environ Res Public Health. 2012;9:100-9. doi:10.3390/ijerph9010100.

6. Bergman B, Carlsson GE Clinical long-term study of complete denture wearers. J Prosthet Dent. 1985;53:56-61. doi: 10.1016/0022-3913(85)90066-6.

7. Budtz-Jørgensen E Oral mucosal lesions associated with the wearing of removable dentures. J Oral Pathol. 1981;10:65-80. doi: 10.1111/j.1600-0714.1981. tb01251.x.

8. Tallgren A, Lang BR, Miller RL Longitudinal study of soft-tissue profile changes in patients receiving immediate complete dentures. Int $\mathrm{J}$ Prosthodont. 1991;4:9-16. doi.

9. Shinkai RS, Hatch JP, Rugh JD, Sakai S, Mobley CC, Saunders MJ Dietary intake in edentulous subjects with good and poor quality complete dentures. JProsthet Dent. 2002;87:490-8. doi: 10.1067/mpr.2002.124093.

10. Fiske J, Davis DM, Frances C, Gelbier S The emotional effects of tooth loss in edentulous people. Br Dent J. 1998;184:90-3; discussion 79. doi: 10.1038/ sj.bdj.4809551.

11. Fiske J, Davis DM, Leung KC, McMillan AS, Scott BJ The emotional effects of tooth loss in partially dentate people attending prosthodontic clinics in dental schools in England, Scotland and Hong Kong: a preliminary investigation. Int Dent J. 2001;51:457-62. doi:10.1002/j.1875-595x.2001. tb00860.x.
12. Davis DM, Fiske J, Scott B, Radford DR. The emotional effects of tooth loss in a group of partially dentate people: a quantitative study. Eur J Prosthodont Restor Dent. 2001 Jun;9(2):53-7.PMID: 11803889.

13. Nordenram G, Davidson T, Gynther G, Helgesson G, Hultin M, Jemt T, etal. Qualitative studies of patients' perceptions of loss of teeth, the edentulous state and prosthetic rehabilitation: a systematic review with meta-synthesis. Acta Odontol Scand. 2013;71:937-51. doi: 10.3109/00016357.2012.734421.

14. Batista MJ, Lawrence HP, de Sousa Mda L Impact of tooth loss related to number and position on oral health quality of life among adults. Health Qual Life Outcomes. 2014;12:165. doi:10.1186/s12955-014-0165-5.

15. Hama Y, Kubota C, Moriya S, Onda R, Watanabe Y, Minakuchi SFactors related to removable denture use in independent older people: A crosssectional study. J Oral Rehabil. 2020;47:998-1006. doi: 10.1111/joor.13022.

16. Anjum MS, Monica M, Rao KY, Reddy PP, Hameed IA, Jyothi MJJoIAoPHD Does tooth loss have an emotional effect? A cross-sectional and comparative study on nondenture wearers and complete denture wearers. J Indian Assoc Public Health Dent. 2017;15(3):247-51. doi:10.4103/jiaphd. jiaphd $46 \_17$

17. Khan S, Chikte U, Omar R Impact of Removable Partial Dental Prostheses on the Oral Health-Related Quality of Life of a South African Cohort with Varied Distributions of Missing Posterior Teeth. J Prosthodont. 2019;28:e434-e9. doi: 10.1111/jopr.12692.

18. Rosing K, Christensen LB, Øzhayat EB Associations between tooth loss, prostheses and self-reported oral health, general health, socioeconomic position and satisfaction with life. J Oral Rehabil. 2019;46:1047-54. doi: 10.1111/joor.12836.

19. Fueki K, Igarashi Y, Maeda Y, Baba K, Koyano K, Sasaki K, et al. Effect of prosthetic restoration on masticatory function in patients with shortened dental arches: a multicentre study. J Oral Rehabil. 2016;43:534-42. doi: 10.1111/ joor.12387.

20. de Souza FN, de Siqueira Gomes C, Rodrigues AR, Tiossi R, de Gouvêa CV, de Almeida CC Partially Edentulous Arches: A5-Year Survey of Patients Treated at the Fluminense Federal University Removable Prosthodontics Clinics in Brazil. J Prosthodont. 2015;24:447-51. doi: 10.1111/jopr.12225.

\section{Mohammed Sayed}

(Corresponding address)

Department of Prosthetic Dental Sciences, Jazan University College of Dentistry

Jazan 45142, Saudi Arabia.

Date submitted: 2020 Jul 09

Email: drsayed203@gmail.com 